\title{
Conductimetry: a rapid alternative technique for chlorides determination in cheese
}

\author{
Jessica Aguirre-Londoño ${ }^{1}$; Víctor Alexander Aristizabal-Ferreira ${ }^{1}$; \\ Sandra Patricia Castro-Narváez ${ }^{1, *}$; Juan Sebastián Ramírez-Navas ${ }^{1,2, *}$
}

Edited by

Juan Carlos Salcedo-Reyes

(salcedo.juan@javeriana.edu.co)

1. Universidad Santiago de Cali,

Facultad de Ciencias Básicas,

Programa de Química, GIEMA,

Calle 5 \# 62-00, Cali, Colombia,

A.A. 4102.

2. Universidad del Valle,

Facultad de Ingeniería,

Escuela de Ingeniería de Alimentos,

GIPAB, Calle 13 \# 100-00,

Cali, Colombia, A.A. 25360.

*juan.sebastian.ramirez@correounivalle.edu.co

Received: 01-02-2018

Accepted: 13-02-2019

Published on line: 10-04-2019

Citation: Aguirre-Londoño J,

Aristizabal-Ferreira VA, Castro-Narváez SP,

Ramírez-Navas JS. Conductimetry: a

rapid alternative technique for chlorides

determination in cheese,

Universitas Scientiarum, 24(2): 307-322, 2019.

doi: 10.11144/Javeriana.SC24-2.cara

Funding:

N.A.

Electronic supplementary material: N.A.

OPEN ACCESS

\begin{abstract}
The correlation of two instrumental techniques for chlorides determination in Colombian cheese, Queso Molido Nariñense (a type of white cheese), was analyzed. Potentiometry of chloride precipitation is the standard technique to determined salt in cheese. Conductimetry is an alternative technique. Samples of Queso Molido Nariñense were made. In the processed cheeses the salt concentration $(\mathrm{NaCl}: 0.5 \%, 0.8 \%, 1.0 \%, 2.0 \%, 3.0 \%$ and $6.0 \%)$ was varied. Chlorides were determined by titration with silver nitrate in the potentiometric technique. In the conductimetric technique, each sample was analyzed by direct measuring its conductivity at room temperature. It was found that there is an adequate correlation between potentiometry and conductimetry. A maximum concentration of $2 \% \mathrm{NaCl}$ in cheese is equivalent to $2.9 \mathrm{~S} / \mathrm{cm}$ for conductivity readings. Additionally, it was verified that the conductimetry constitutes an analytically reliable technique for the determination of chlorides in cheese, it is friendlier to the environment, cheaper and faster.
\end{abstract}

Keywords: Colombian cheese; white cheese; sodium chloride; potentiometry; conductimetry.

\section{Introduction}

Queso Molido Nariñense is a kind of fresh cheese, not acid, made with cow's milk. It is one of the typical Colombian cheeses made in the southern part of the country. Ramírez-Navas (2010) described the process to make this cheese, with a high content of salt. The salting process has great influence on cheese quality due to its effects on its composition, microflora and enzymatic activity (Guinee, 2004). Salt increases the osmotic pressure in the aqueous phase of food, causing the dehydration of the bacteria, hence their death or preventing their growth and proliferation (Cruz et al., 2011). 
Some physicochemical studies in a large variety of cheeses show that salt has an important impact on rheological and textural aspects and shelf life. However, one of the main limitations currently in the determination of salt in cheeses is the environmental impact that the chemical tests cause due to the use of silver nitrate (AOAC-983.14, 1997; IDF-88A, 1988). Therefore, it is necessary to search for new analytical techniques.

To evaluate the saltiness of cheese in the manufacturing process, the traditional way is the determination of chlorides by potentiometry (Ramírez Navas et al., 2017). In the literature, there are several methods to determine the salt content in foods; for example, Mercurimetry is a volumetric method using a standard solution of mercuric nitrate in nitric acid medium and diphenylcarbazone as an indicator, for the direct evaluation of chlorides in cheeses (Farias \& Boscan, 1980). The Mohr method (Argentometry, $\mathrm{AgNO}_{3}$ as a titrant) based on the fact that soluble chlorides precipitate in acidic solutions in the presence of silver nitrate to form a pale silver chloride solid. The chromate ion is used as an indicator, and the detection of the endpoint is carried out by the formation of the second precipitate of red-orange silver chromate (Sierra Alonso, Morante Zarcero \& Pérez Quintanilla, 2007). The Charpentier-Volhard method, based on determining the content of chlorides by recoil, in which a solution of nitric acid and an excess amount of silver nitrate is added to the sample. Titration determines excess silver ions with a standard solution of an alkali thiocyanate. The indicator is a ferric alum, and the equivalence point is detected by the appearance of a red color due to the formation of the thiocyanate iron complex (III) (Burgot, 2012). The selective ion electrode potentiometry (ISE) employs a solid-state electrode that develops a voltage due to an ion exchange that is generated between the sample and the inorganic membrane. An equilibrium mechanism occurs due to the limited solubility of the membrane material in the sample. Chloride precipitation potentiometry uses a silver electrode as an indicator and a reference electrode. The potential difference experienced by the indicator electrode in the presence of silver ions generates a potential difference that is easily detectable with a multimeter. The Silver ions reaction with chloride anions can estimate the concentration of this anion in the study system (AOAC-983.14, 1997; Harris, 2007; IDF-88A, 1988). Finally, the conductimetric method, where the percentage of chlorides is measured with an automatic titrator, uses an acid chloride buffer containing polyvinyl alcohol, glacial acetic acid, nitric acid and sodium chloride to calibrate and maintain an electrolytic bridge between the two indicator electrodes. A standard chloride solution, consisting of sodium chloride, antimycotic preservative and deionized water, is used to standardize the equipment (González \& Medina, 2005). However, information available about new methods of salt determinations in cheese is limited in the literature. 
Potentiometric methods of analysis are simple and economical (Skoog, Holler \& Nieman, 2001). However, the conductimetric method is characterized by being a clean technique. The aim of this study was to evaluate the correlation between two instrumental techniques for the determination of chlorides in cheese, potentiometry as standard technique and conductimetry as an alternative technique.

\section{Material and methods}

\section{Manufacture of cheeses}

The complete random design was used in this investigation. In the Queso Molido Nariñense manufactured with salt concentration $(\mathrm{NaCl}: 0.5 \%, 0.8 \%$, $1.0 \%, 2.0 \%, 3.0 \%$ and $6.0 \%$ ) was varied. Each day three cheeses were made, each one with different concentration of $\mathrm{NaCl}$. For each $\mathrm{NaCl}$ concentration, three cheese samples were produced. Each batch was analyzed in triplicate, giving a total of 54 samples. The order in which the cheeses were made was selected at random. The samples of cheeses were manufactured in the laboratories of the Universidad Santiago de Cali.

For the manufacture of cheese samples, the recommendations made by Ramírez-Navas (2010) were followed. Standardized and pasteurized commercial milk was obtained from Lácteos Uno A (Candelaria, VA, Colombia). The protein: fat ratio of milk was 0.96: 1. Milk was stored at $6{ }^{\circ} \mathrm{C}$ before cheese manufacturing. To make cheese, milk was disposing in vats of $\sim 15 \mathrm{~L}$ ( $\sim 10 \mathrm{~L}$ of milk per treatment). Milk was heated to $36^{\circ} \mathrm{C}$, and $\mathrm{CaCl}_{2}$ was added to a final concentration of $0.02 \% \mathrm{w} / \mathrm{v}$. Microbial rennet (2 $200 \mathrm{IMCU} / \mathrm{mL}$, Mucur Pusillus, EC 3.4.23.23, Marzyme ${ }^{\circledR}$, Danisco) was diluted in deionized water $(1: 10)$ and added to the milk at a ratio of $0.20 \mathrm{~mL} / \mathrm{L}$. After $40 \mathrm{~min}$, when the curd reached the required firmness, it was cut to the appropriate grain size (about half a grain of rice). The mixture of curd and whey particles was stirred and warmed at $0.5^{\circ} \mathrm{C} /$ min until it reached $45^{\circ} \mathrm{C}$, to reduce moisture in the curd grains. The stirring was then stopped, and the mixture was filtered through a nylon mesh to remove the whey. The grains of curd were ground and salted. Molding was done in cylindrical molds (diameter $11.4 \mathrm{~cm}$, height $5 \mathrm{~cm})$ at decreasing temperature $\left(\sim 40^{\circ} \mathrm{C}\right.$ at room temperature). The cheese samples were packaged, coded according to the salt content and stored at $4{ }^{\circ} \mathrm{C}$ for seven days before salt determination.

\section{Preparations of samples}

Samples of each cheese were collected according to the IDF (2008). Samples $(\sim 50 \mathrm{~g})$ were homogenized separately in a food processor, then were packaged and stored at $4{ }^{\circ} \mathrm{C}$ for two hours. The homogenized samples were analyzed the same day. 


\section{Potentiometry}

Potentiometric analyzes were performed using a Tech (TM-108), Calomel electrode (Fisher), a silver electrode (99.9\% purity silver wire, Alpha Aesar, Ward Hill, MA, USA). With analytical grade, Nitric acid and silver nitrate (Panreac AppliChem, Barcelona, Spain) as a standardization agent (AOAC-971.27D, 1997) and $\mathrm{NaCl}$ (Carlo Erba reagents, Cornaredo, MI, Italy). For the determination of $\mathrm{NaCl}$ in cheeses, the method of $\mathrm{AOAC}$ 983.14 (AOAC-983.14, 1997) was used, which consists in the determination of chlorides by potentiometric titration with silver nitrate. $3 \mathrm{~g}$ of the homogenized sample was weighed and mixed with $30 \mathrm{~mL}$ of water at $55^{\circ} \mathrm{C}$. $2 \mathrm{~mL}$ of $\mathrm{HNO}_{3}$ (in $0.5 \mathrm{~mL}$ aliquots) was added and titrated with $\mathrm{AgNO}_{3}$. Samples were analyzed in triplicate.

\section{Conductimetry}

The technic was validated (specificity, linearity, accuracy, precision and verification) to assurance the reproducibility and repeatability (information of validation is not presented in this work). Conductimetric analyzes were performed using a VWR Scientific model 2052 conductivity meter (Eugene, OR, USA). A calibration curve was elaborated with $\mathrm{NaCl}$ standards between $0.01 \%-0.7 \%$. $3 \mathrm{~g}$ of the homogenized sample was weighed and mixed with $30 \mathrm{~mL}$ of water at $55^{\circ} \mathrm{C}$. Each sample was analyzed by measuring its conductivity at room temperature $\left(20^{\circ} \mathrm{C}\right)$. The analyzes were performed in triplicate.

\section{Statistical analysis}

Data obtained from the analytical response of chlorides of cheese samples to different concentrations of $\mathrm{NaCl}$ by potentiometric and conductimetric methods were analyzed statistically using the SPSS Statistics program (V. 18.0.0-SPSS Inc.). Using analysis of variance ANOVA, the significant differences between the lots of the same concentration of $\mathrm{NaCl}$ were evaluated. As a post hoc analysis, the Tuckey test with $\alpha$ of 0.05 was used. The significance of the correlation was determined by applying the t-Student test with data related to $n-1 d f$, where $n$ is the actual number of data points and $d f$ are degrees of freedom. Graphs, regression equations and coefficients of determination $\left(\mathrm{r}^{2}\right)$ were obtained using Excel 2010 (Microsoft Office Excel, 2010).

\section{Results and Discussion}

Queso Molido Nariñense was selected for this investigation because it does not loose salt in the process. The salt is added at the end of process before grinding the curd in the mill. 


\section{Analytical techniques}

\section{Potentiometry}

Fig. 1 shows the potentiometric titration curve or the relationship between potential and volume of silver nitrate used in the determination of salt in cheese. Fig. 2 shows the first and second derivatives of the potentiometric titration curve with $\mathrm{AgNO}_{3}$ to determine $\mathrm{NaCl}$ in cheeses.

Fig. 1 shows the increase in the potential resulting from the reduction of $\mathrm{Ag}^{+}$ions (Eq. 1) free from the $\mathrm{AgCl}$ solution (Eq. 2) formed in the reaction of silver nitrate with sodium chloride (Eq. 3) and which is detected by the silver indicating electrode in the presence of the Calomel reference electrode $\left(\mathrm{E}_{\mathrm{ref}}\right)$. The potential is given by the Nernst equation (Eq. 4).

$$
\begin{array}{r}
\mathrm{Ag}^{+}+1 \mathrm{e}^{-} \rightarrow \mathrm{AgE}^{\circ}=0.799 \mathrm{~V} \\
\mathrm{AgCl}(\mathrm{s}) \rightarrow \mathrm{Ag}^{+}(\mathrm{ac})+\mathrm{Cl}^{-}(\mathrm{ac}) \\
\mathrm{AgNO}_{3}+\mathrm{NaCl} \rightarrow \mathrm{AgCl}(\mathrm{s})+\mathrm{NaNO}_{3} \\
E=E^{\circ}-0.05916 \mathrm{Log} \frac{1}{\left[A g^{+}\right]}-\mathrm{E}_{\text {ref }}
\end{array}
$$

Where: $\mathrm{E}$ is the cell potential (electromotive force) at the temperature of interest. $\mathrm{E}^{\circ}$ is the standard cell potential. $\mathrm{E}_{\text {ref }}$ is the reference potential. $\left[\mathrm{Ag}^{+}\right]$ is the $\mathrm{Ag}$ concentration.

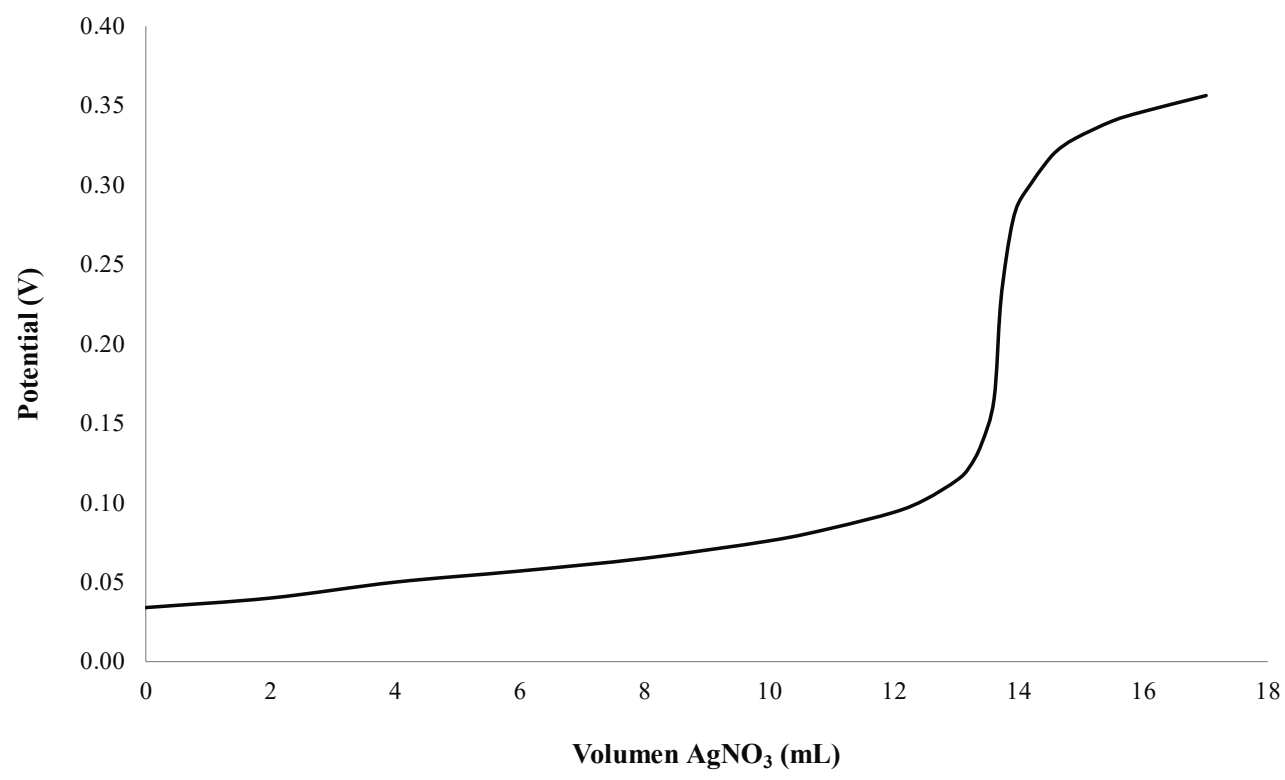

Figure 1. Potentiometric titration with silver nitrate to determine $\mathrm{NaCl}$ in cheese. 

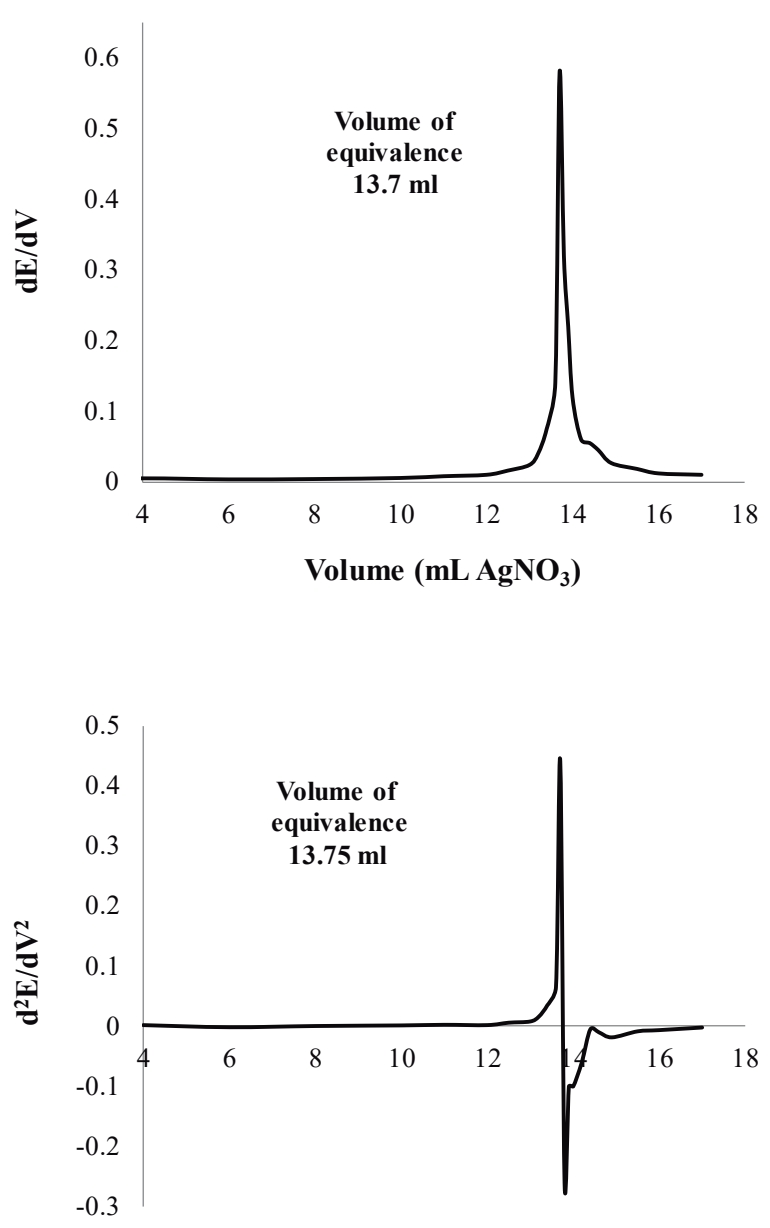

Volume (mL $\left.\mathrm{AgNO}_{3}\right)$

Figure 2. First and second derivatives of the potentiometric titration curve with $\mathrm{AgNO}_{3}$ to determine $\mathrm{NaCl}$ in cheeses.

Applying the first and second derivatives (Fig. 2), the volume of equivalence of the titration was established with certainty. The information on the derivatives, the silver nitrate concentration and the sample volume $(30 \mathrm{~mL})$ allowed determining the concentration of chlorides in each sample as the reaction exhibited a $1: 1$ ratio.

\section{Conductimetry}

The determination of chlorides by this technique was performed by interpolation of the conductivity of the sample concerning the calibration curve between $\mathrm{NaCl}$ concentration (in molarity) vs. conductivity (Fig. 3).

The calibration curve has a correlation coefficient close to unity that ensures that there is a high correlation with the conductivity at room temperature $\left(20^{\circ} \mathrm{C}\right)$ in the concentration range. 


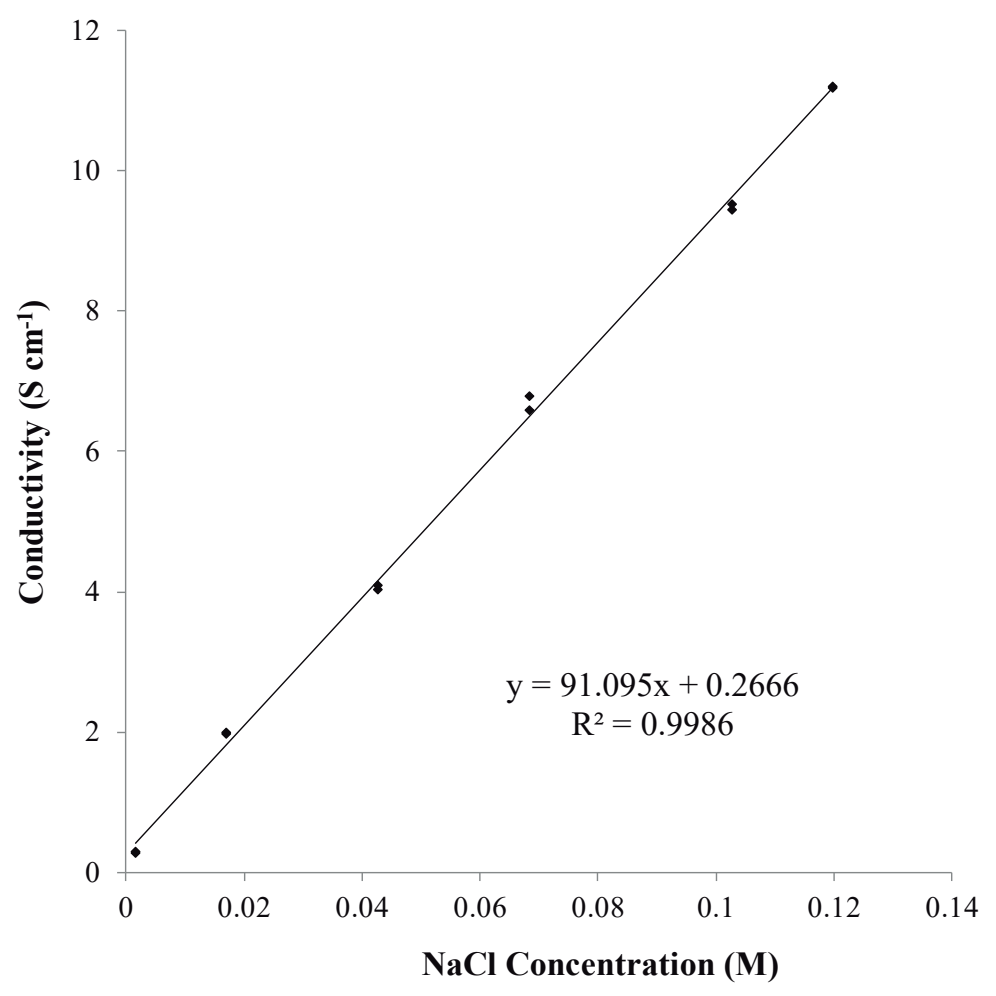

Figure 3. $\mathrm{NaCl}$ Calibration Curve by conductimetry.

\section{Repeatability and reproducibility}

Table 1 shows the repeatability and reproducibility of $\mathrm{NaCl}$ measurements by potentiometry and conductimetry.

The potentiometry technique presents better analytical results regarding repeatability and reproducibility in $\mathrm{NaCl}$ determinations in cheese samples. The percentages of relative standard deviation (\% RSD) were lower for the potentiometric technique. However, conductimetry becomes an excellent alternative for analysis because the \% RSD values do not exceed $2.4 \%$, indicating that it is a reliable technique and meets the analytical requirements (Skoog et al., 2001).

\section{Correlation of instrumental techniques}

Table 2 presents the results (mean \pm standard deviation) of the potentiometric and conductimetric quantification of the concentration percentage of $\mathrm{NaCl}$ in the cheese samples with theoretical values between $0.5 \%$ and $6.0 \%$

Comparing the amount of salt added to the cheese and the result obtained by the two techniques, both techniques present slightly higher values when the cheese has concentrations below $2 \% \mathrm{NaCl}$. The latter may be associated with the number of chlorides present in natural milk (1.8\%) (Alais, 2003), 
Table 1. Repeatability and reproducibility in the determination of $\mathrm{NaCl}$ in cheeses by potentiometry and conductimetry.

\begin{tabular}{|ccccccc}
\hline \multirow{2}{*}{ Technique } & \multicolumn{3}{c}{ Repeatability } & \multicolumn{3}{c}{ Reproducibility } \\
& Mean & $\begin{array}{c}\text { Standard } \\
\text { Deviation }\end{array}$ & \% RSD & Mean & $\begin{array}{c}\text { Standard } \\
\text { Deviation }\end{array}$ & \% RSD \\
\hline Potentiometry & 1.039 & $1.971 \times 10^{-2}$ & 1.898 & 0.599 & $1.357 \times 10^{-3}$ & 0.227 \\
\hline Conductimetry & 0.991 & $2.35 \times 10^{-2}$ & 2.37 & 0.628 & $1.160 \times 10^{-2}$ & 1.849 \\
\hline
\end{tabular}

because this contribution is representative at these salt concentrations. For concentrations higher than $2 \%$ the two techniques exhibit lower concentrations than those added to the cheese, this can be explained because there is an inverse relationship between moisture and salt levels in cheese (Fox et al., 2000). The higher concentration of salt will be a greater waste and with it loss of soluble substances such as salt. Also, it should be noted that the cheese with the highest concentration of salt presented a harder and brittle texture, which is because it had greater dehydration by draining.

In Fig. 4 it is observed that there is a high correlation $\left(r^{2}=0.998\right)$ between the results obtained between both techniques. In Fig. 5 it is observed the correlation of each of the techniques concerning the percentage of $\mathrm{NaCl}$ added in the preparation of the cheese.

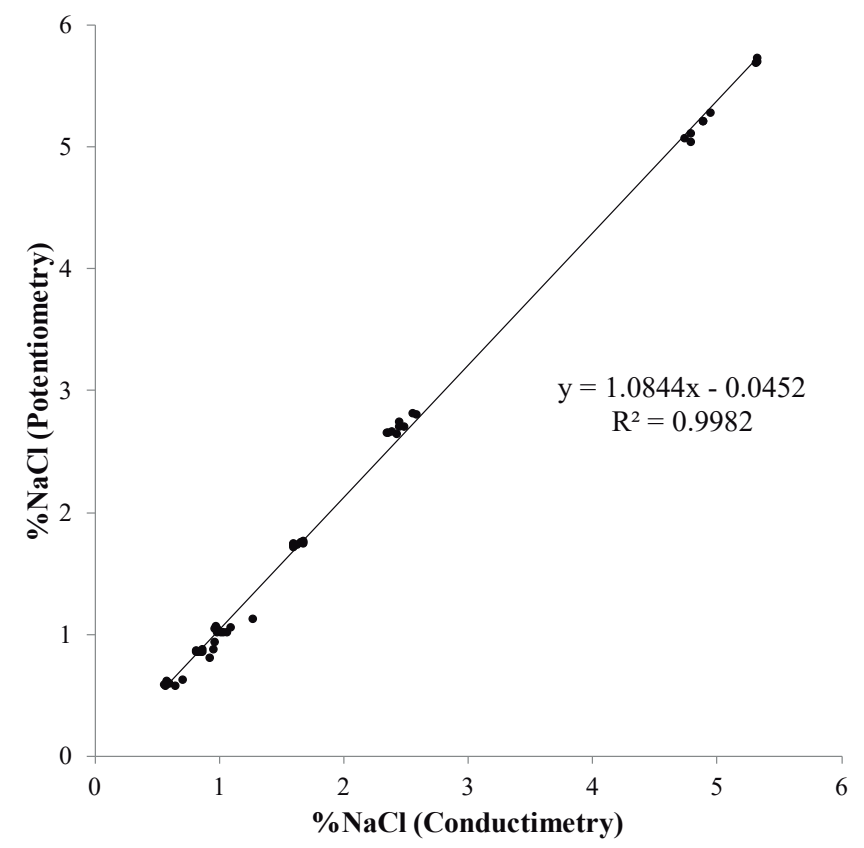

Figure 4. Correlation of $\% \mathrm{NaCl}$ results by potentiometry and conductimetry. 
Table 2. Results (mean \pm standard deviation) of the correlation of instrumental techniques.

\begin{tabular}{ccc}
\hline $\begin{array}{c}\text { NaCl added } \\
\text { to cheese }(\%)\end{array}$ & $\begin{array}{c}\text { Potentiometry } \\
(\% \mathbf{~ N a C l})\end{array}$ & $\begin{array}{c}\text { Conductimetry } \\
(\% \mathbf{~ N a C l})\end{array}$ \\
\hline 0.5 & $0.62^{\mathrm{a}} \pm 0.073$ & $0.64^{\mathrm{a}} \pm 0.115$ \\
\hline 0.8 & $0.87^{\mathrm{a}} \pm 0.026$ & $0.87^{\mathrm{a}} \pm 0.056$ \\
\hline 1 & $1.05^{\mathrm{a}} \pm 0.033$ & $1.04^{\mathrm{a}} \pm 0.096$ \\
\hline 2 & $1.74^{\mathrm{a}} \pm 0.015$ & $1.63^{\mathrm{a}} \pm 0.037$ \\
\hline 3 & $2.71^{\mathrm{a}} \pm 0.063$ & $2.45^{\mathrm{a}} \pm 0.082$ \\
\hline 6 & $5.34^{\mathrm{a}} \pm 0.286$ & $5.00^{\mathrm{b}} \pm 0.248$ \\
\hline
\end{tabular}

The values of $\mathrm{r}^{2}$ higher than 0.98 allow establishing that both methods have a high correlation. The potentiometric technique has a higher sensitivity and linearity since, respectively, its slope and correlation coefficient are higher than those obtained with the conductimetric technique.

Table 3 shows the results of the t-test for the three statistical comparisons ( $0.5 \%$ to $6 \%, 0.5 \%$ to $3 \%$ and $0.5 \%$ to $2 \%$ ) between the two analytical techniques.

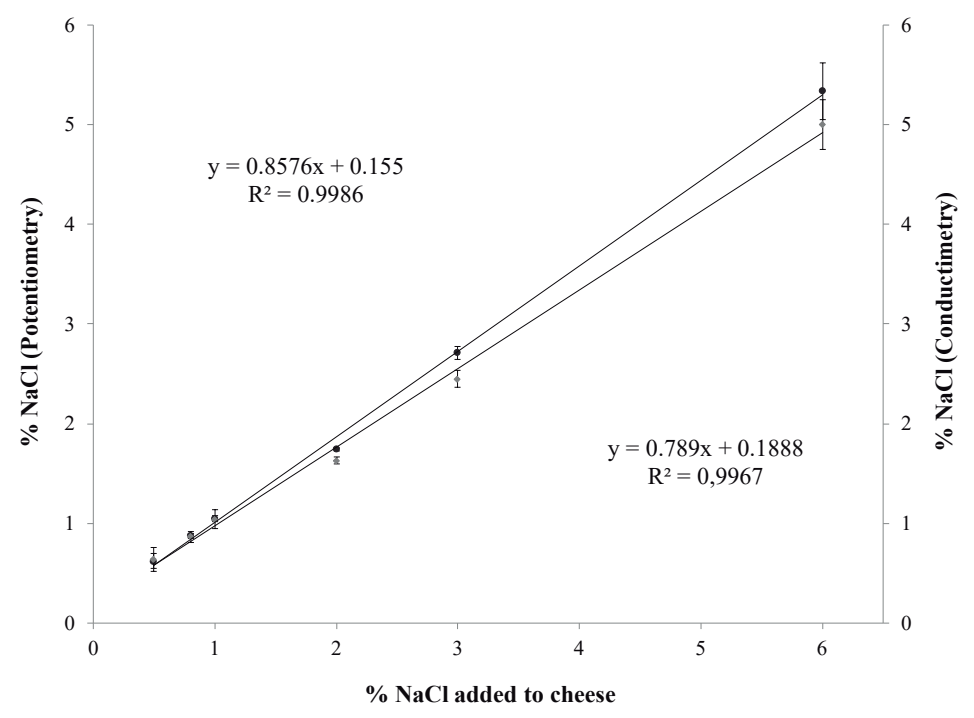

Figure 5. Correlation of the results of potentiometry and conductimetry concerning \% $\mathrm{NaCl}$ added in the cheese samples ( $\bullet$ potenciometry, $\diamond$ conductimetry.) 
Table 3. T-test of related samples between potentiometry and conductimetry technique.

\begin{tabular}{|c|c|c|c|c|c|c|c|c|}
\hline & & & Related & ifference & & & & \\
\hline & & & & $\begin{array}{r}95 \% \mathrm{C} \\
\text { inte } \\
\text { diff }\end{array}$ & $\begin{array}{l}\text { fidenc } \\
\text { l for } \\
\text { ence }\end{array}$ & & & \\
\hline $\begin{array}{l}\text { Results of } \% \mathrm{NaCl} \\
\text { by potentiometry } \\
\text { vs. conductimetry }\end{array}$ & Mean & $\begin{array}{c}\text { Typical } \\
\text { Deviation }\end{array}$ & $\begin{array}{l}\text { Typical } \\
\text { media } \\
\text { error }\end{array}$ & Lower & Higher & $\mathrm{t}$ & F.d. & $\begin{array}{r}\text { Significanc } \\
\text { (bilateral) }\end{array}$ \\
\hline $\begin{array}{l}\text { From } 0.5 \% \\
\text { to } 6 \% \mathrm{de} \mathrm{NaCl}\end{array}$ & 0.121 & 0.150 & 0.021 & 0.078 & 0.164 & 5.988 & 53 & 0.000 \\
\hline $\begin{array}{l}\text { From } 0.5 \% \\
\text { to } 3 \% \text { de } \mathrm{NaCl}\end{array}$ & 0.073 & 0.119 & 0.019 & 0.036 & 0.111 & 4.345 & 44 & 0.000 \\
\hline $\begin{array}{l}\text { From } 0.5 \% \\
\text { to } 2 \% \mathrm{NaCl}\end{array}$ & 0.020 & 0.070 & 0.012 & -0.005 & 0.046 & 1.646 & 35 & 0.110 \\
\hline
\end{tabular}

It is observed that for the first interval, the level of significance $(0.000)$ is lower than the established alpha value $(\alpha=0.05)$ and the experimental $t$ of 5.988 is greater than the tabulated of 2.006 . Therefore, the null hypothesis is rejected, concluding that there are significant differences between the two instrumental techniques and the data range. For the second interval, the level of significance is still lower than that established, and the experimental $\mathrm{t}$ (4.345) is greater than the tabulation (2.015). Therefore, the null hypothesis is rejected again, and significant differences are assumed between the two instrumental techniques. For the third interval, it is obtained that the level of significance is greater than the established alpha value and the experimental " $\mathrm{t}$ " (1.646) is less than the tabulated (2.040). Therefore, the null hypothesis is accepted, concluding that there are no significant differences between the results of the two instrumental techniques at a concentration of $2 \% \mathrm{NaCl}$ in cheese samples. It is also observed that the standard deviation and the typical error of the mean decreased between the selected intervals, i.e., that the dispersion of the sample means decreases around the population mean (Miller \& Miller, 2010).

The calculation of the differences between the results of the techniques shows that up to a concentration of $2 \% \mathrm{NaCl}$ these values are distributed below and above zero (Fig. 6), according to random type errors. For concentrations above $2 \%$, the differences are positive, indicating a marked tendency for conductimetry to generate values below the real for high concentrations. The latter might be due to a loss of linearity and associated with systematic errors.

Therefore, it is concluded that there is an adequate correlation between potentiometry (reference method) and conductimetry (alternative method) 


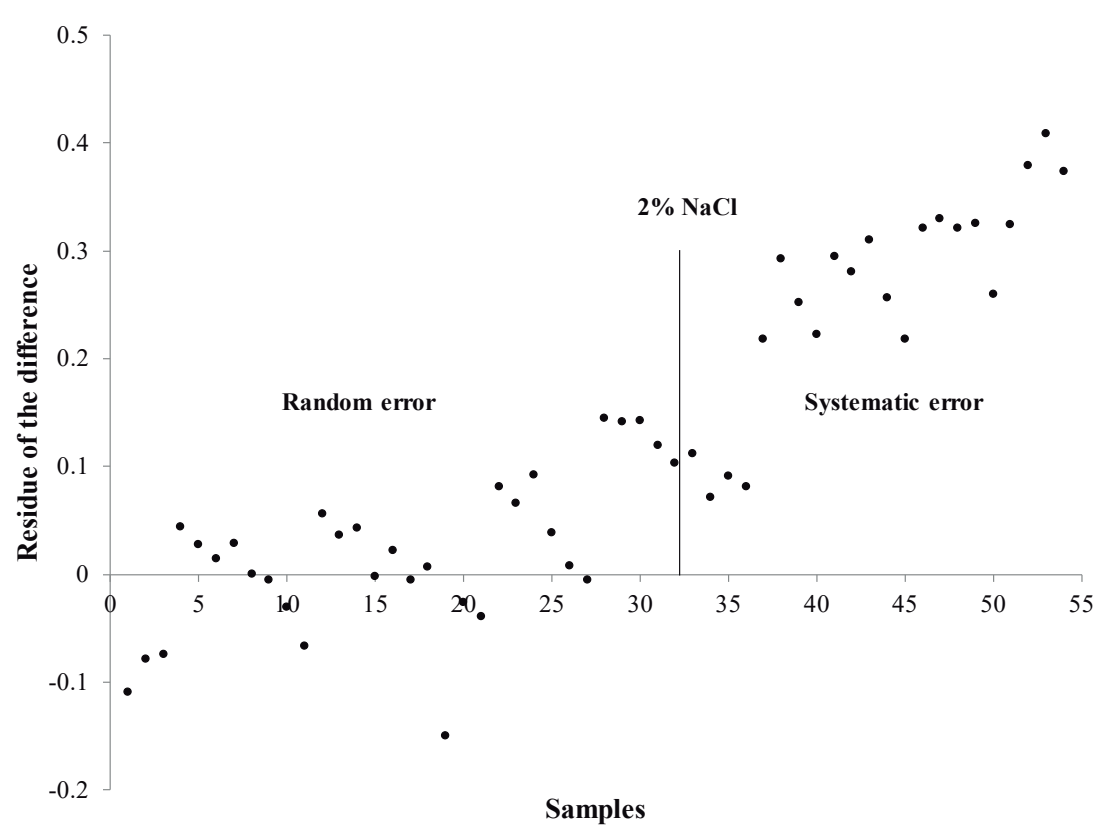

Figure 6. Residues of the potentiometry and conductimetry method differences.

for salt analysis in cheeses with a maximum concentration of $2 \% \mathrm{NaCl}$ or equivalent for conductivity readings up to $2.9 \mathrm{~S} / \mathrm{cm}$. However, cheeses with concentrations above $2 \% \mathrm{NaCl}$ can be analyzed for conductimetry by making sample dilutions, so their conductivity does not exceed $2.9 \mathrm{~S} / \mathrm{cm}$.

\section{Conclusions}

The potentiometry has a higher sensitivity and linearity since, respectively, its slope and correlation coefficient are higher than those obtained with the conductimetry. However, the conductimetry shows environmental advantages since it is a technique that does not generate toxic wastes. It shows an operational advantage since it is an instrument easy to handle. Additionally, it shows economic advantage since it is possible to analyze a lot of samples in short time without requiring expensive reagents., indicating that it is a reliable technique and a good alternative to the potentiometry for chlorides determination in cheese.

\section{Acknowledgements}

The authors thank Universidad Santiago de Cali and its authorities for providing the facilities (logistics and equipment) to conduct this study.

\section{Conflict of interest}

The authors declare that they have no conflicts of interest to disclose. 


\section{References}

Alais C. Ciencia de la leche. Principio de tecnica lechera (4 ed.). Barcelona, España: Reverté S.A. 2003.

AOAC-971.27D. Sodium Chloride in Canned Vegetables. In Standardization (Vol. II. 17th ed., International standard 971.27D). Gaithersburg, MD: Association of Official Analytical Chemists. 1997.

AOAC-983.14. Chloride in Cheese. Potentiometric Method. In (Vol. II. 17th ed., International standard 983.14). Gaithersburg, MD: Association of Official Analytical Chemists. 1997.

Burgot JL. Ionic Equilibria in Analytical Chemistry (Springer Ed.). New York, USA: Springer. 2012.

doi: 10.1007/978-1-4419-8382-4

Cruz AG, Faria JAF, Pollonio MAR, Bolini HMA, Celeghini RMS, Granato D, Shah NP. Cheeses with reduced sodium content: Effects on functionality, public health benefits, and sensory properties, Trends in Food Science \& Technology, 22(6): 276-291, 2011.

doi: 10.1016/j.tifs.2011.02.003

Farias J, Boscan LA. Aplicaciones de la mercurimetria a la determinacion de cloruros en productos lacteos, Acta Cientifica Venezolana, 31(1): 235, 1980.

Fox PF, Cogan TM, McSweeney PLH, Guinee TP. Fundamentals of cheese science. Gaithersburg, MD: Aspen Pub. 2000.

González LIJ, Medina GAL. Determinacion de cloruros en leche pasteurizada consumida en el estado Merida-Venezuela y su incidencia en el Punto Crioscópico, Revista del Instituto Nacional de Higiene Rafael Rangel, 36(1): 2-17, 2005.

Guinee TP. Salting and the role of salt in cheese, International Journal of Dairy Technology, 57(2-3): 99-109, 2004.

doi: 10.1111/j.1471-0307.2004.00145.x

Harris D. Quantitative Chemical Analysis (7 ed.). NY, USA: W. H. Freeman and Company. 2007. 
IDF-88A. Cheese and processed cheese: Determination of chloride content (potentiometric titration method). In (Vol. International standard 88A). Brussels, Belgium: International Dairy Federation. 1988.

IDF. Milk and milk products Guidance on sampling. In (Vol. International standard 050). Brussels, Belgium: International Dairy Federation. 2008.

Miller JN, Miller JC. Statistics and chemometrics for analytical chemistry (6 ed.). USA: Prentice Hall. 2010.

Ramírez-Navas JS. Queso molido nariñense, Tecnología Láctea Latinoamericana, 59: 56-59, 2010.

Ramírez-Navas JS, Aguirre-Londoño J, Aristizabal-Ferreira VA, Castro-Narváez S. La sal en el queso: diversas interacciones, Agronomia Mesoamericana, 28(1): 303-316, 2017.

doi: $10.15517 /$ am.v28i1.21909

Sierra Alonso I, Morante Zarcero S, Pérez Quintanilla D. Experimentación en química analítica. Madrid, España: Dykinson, S.L. 2007.

Skoog DA, Holler FJ, Nieman TA. Principios de análisis instrumental: McGraw-Hill. Madrid, España. 2001. 


\section{Conductimetría: una técnica alternative rápida para determinación de cloruros en queso}

Resumen: Se analizó la correlación de dos técnicas instrumentales para la determinación de cloruros en queso colombiano, Queso Molido Nariñense (un tipo de queso blanco). La potenciometría de precipitación de cloruro es la técnica estándar para determinación de sal en queso. La conductimetría es una técnica alternativa. Se tomaron muestras de Queso Molido Nariñense utilizando quesos manufacturados con distintas concentraciones de sal ( $\mathrm{NaCl}: 0.5 \%, 0.8 \%, 1.0 \%, 2.0 \%, 3.0 \%$ y $6.0 \%$ ). Los cloruros se determinaron por titulación con nitrato de plata en la técnica potenciométrica. En la técnica conductimétrica cada muestra fue analizada por medición directa de su conductividad a temperatura ambiente. Se encontró que hay una correlación adecuada entre la potenciometría y la conductimetría. Una concentración máxima de $2 \% \mathrm{NaCl}$ en queso es equivalente a $2.9 \mathrm{~S} / \mathrm{cm}$ para lecturas de conductividad. Adicionalmente, se verificó que la conductimetría constituye una técnica analítica confiable para la determinación de cloruros en queso: es más amigable con el ambiente, más barata y más rápida.

Palabras clave: queso colombiano; queso blanco; cloruro de sodio; potenciometría; conductimetría. 


\section{Conductometria: uma técnica alternativa e rápida para a determinação de cloretos no queijo}

Resumo: A correlação entre duas técnicas instrumentais para a determinação de cloretos em queijo colombiano, Queso Molido Nariñense (um tipo de queijo branco), foi analisada. A potenciometria de precipitação de cloretos é a técnica padrão para determinar o sal no queijo. A conductometria é uma técnica alternativa. Amostras de Queso Molido Nariñense foram colectadas de queijos fabricados com diferentes concentrações de sal $(\mathrm{NaCl}: 0.5 \%$, $0.8 \%, 1.0 \%, 2.0 \%, 3.0 \%$ e $6.0 \%$ ). Os cloretos foram determinados por titulação com nitrato de prata na técnica potenciométrica. $\mathrm{Na}$ técnica conductométrica, cada amostra foi analisada medindo diretamente sua condutividade à temperatura ambiente. Achamos uma correlação adequada entre a potenciometria e a conductometria. Uma concentração máxima de $2 \% \mathrm{NaCl}$ no queijo foi equivalente a $2,9 \mathrm{~S} / \mathrm{cm}$ nas leituras de condutividade. Adicionalmente, foi verificado que a conductometria constitui uma técnica analítica confiável para a determinação de cloreto no queijo que é mais amigável com o meio ambiente, mais barata e mais rápida do que o método padrão.

Palavras-chave: queijo colombiano; queijo branco; cloreto de sódio; potenciometria; conductometria. 


\section{Jessica Aguirre-Londoño}

Received his BSc. Chemistry in 2013 from the Universidad Santiago de Cali, Cali, Colombia.

ORCID: 0000-0003-1300-6340

\section{Víctor Alexander Aristizabal Ferreira}

Received his BSc. Chemistry in 2013 from the Universidad Santiago de Cali, Cali, Colombia.

ORCID: 0000-0003-0249-4633

\section{Sandra Patricia Castro Narváez}

Received his BSc. Chemistry in 1999 and her MSc. in Chemical in 2004 from the Universidad del Valle, Cali, Colombia. She has worked in programs and projects in the Electrochemistry area at the Universidad Santiago de Cali. She is currently a Full Professor in the Chemistry Program, Basic Science Faculty, Universidad Santiago de Cali. Her research interests include Electrochemistry and Analítical Chemistry. She has several publications in scientific journals.

ORCID: 0000-0002-2023-8935

\section{Juan Sebastian Ramirez-Navas}

Rreceived his BSc. Chemical Engineering in 2003 from the Universidad Central del Ecuador, Quito, Ecuador, and his Ph.D. in Engineering in 2012 from Universidad del Valle, Cali, Colombia. He has worked in programs and projects in the food, chemistry and nutrition areas at the Universidad del Valle (UV), Universidad Santiago de Cali (USC), and Corporación Biotec (CB). He is currently an Assistant Professor in the Food Engineering School, Engineering Faculty, UV; Professor in the Basic Science Faculty, USC, and Researcher in CB. His research interests include physical properties of food, process engineering, dairy science, natural ingredients, and functional food. He has several publications in scientific journals.

ORCID: 0000-0002-6731-2784 